\title{
Een vlinder in China : over efficiëntie en persistentie
}

Citation for published version (APA):

Schotman, P. C. (1998). Een vlinder in China : over efficiëntie en persistentie. Universiteit Maastricht. https://doi.org/10.26481/spe.19980605ps

Document status and date:

Published: 05/06/1998

DOI:

10.26481/spe.19980605ps

Document Version:

Publisher's PDF, also known as Version of record

\section{Please check the document version of this publication:}

- A submitted manuscript is the version of the article upon submission and before peer-review. There can be important differences between the submitted version and the official published version of record.

People interested in the research are advised to contact the author for the final version of the publication, or visit the DOI to the publisher's website.

- The final author version and the galley proof are versions of the publication after peer review.

- The final published version features the final layout of the paper including the volume, issue and page numbers.

Link to publication

\footnotetext{
General rights rights.

- You may freely distribute the URL identifying the publication in the public portal. please follow below link for the End User Agreement:

www.umlib.nl/taverne-license

Take down policy

If you believe that this document breaches copyright please contact us at:

repository@maastrichtuniversity.nl

providing details and we will investigate your claim.
}

Copyright and moral rights for the publications made accessible in the public portal are retained by the authors and/or other copyright owners and it is a condition of accessing publications that users recognise and abide by the legal requirements associated with these

- Users may download and print one copy of any publication from the public portal for the purpose of private study or research.

- You may not further distribute the material or use it for any profit-making activity or commercial gain

If the publication is distributed under the terms of Article $25 \mathrm{fa}$ of the Dutch Copyright Act, indicated by the "Taverne" license above, 


\title{
Een vlinder in China: Over efficiëntie en persistentie
}

\author{
Rede
}

in verkorte vorm uitgesproken bij de aanvaarding van het ambt van hoogleraar Finance and Econometrics, aan de Universiteit van Maastricht op vrijdag 5 juni 1998

door

dr. Peter C. Schotman 
Much of the debate involves theological tenets that are empirically undecidable.

Campbell, Lo and MacKinlay (1997, p4)

Empirical models are invariably simplifications and, in that sense, inevitably false, although as we will see, there is also a sense in which they can be true but unhelpful.

Hendry $(1995, \mathrm{p} 4)$ 
Mijnheer de Rector Magnificus,

Dames en heren,

\section{Inleiding}

Veruit de meest getoetste hypothese in de wereld van beleggen is de efficiënte markt hypothese. Losweg stelt deze hypothese dat koersen op elk moment alle relevante informatie omtrent de waarde van het aandeel weerspiegelen, zodat koersveranderingen zo goed als onvoorspelbaar zijn.

In de econometrie van de afgelopen tien jaar is persistentie veruit de meest onderzochte eigenschap van tijdreeksen. De vraag die men probeert te beantwoorden is in welke mate en voor hoe lang een bepaalde schok doorwerkt. Als bijvoorbeeld nu de inflatie onverwacht een procent hoger is dan verwacht, wat heeft dit dan gemiddeld genomen voor invloed op de inflatie van volgende maand, volgend jaar, of tien jaar later? En wat zijn de gevolgen voor aandelenkoersen over dezelfde horizonnen?

Deze laatste vraag is het onderwerp van mijn oratie. De vraagstelling combineert een kernthema uit de financiering met één uit de econometrie. Daarmee hoop ik recht te doen aan de titel van mijn leerstoel: financiering én econometrie. Meer in het algemeen wil ik laten zien waarom persistentie een belangrijk begrip is bij veel vragen uit de beleggingsleer. En waarom financiële econometrie zich ontwikkelt tot een heel eigen vakgebied, dat steeds meer los komt te staan van econometrie zonder dit bijvoeglijk naamwoord.

Al enige jaren verzorg ik in samenwerking met de sectie Econometrie van deze faculteit het onderwijsblok Empirische Analyse van Financiële Markten voor vierdejaarsstudenten bedrijfseconomie dan wel econometrie. Dit blok beoogt de integratie van financiering en econometrie, en wil aan studenten van beide studierichtingen iets te bieden hebben. Studenten die het blok Empirische Analyse van Financiële Markten 
hebben gelopen, zullen met een groot deel van de inhoud van deze oratie reeds bekend zijn.

\section{Efficiëntie}

Laat ik beginnen met efficiëntie. Studenten aan deze faculteit worden al in hun eerste jaar met deze fundamentele hypothese geconfronteerd. In het blok Investeren en Rapporteren volgen zij de avonturen van een zekere Renate die in de krasloterij een miljoen heeft verdiend. Renate is een slimme student en onderzoekt de mogelijkheden dit geld op de beste manier te beleggen. In een beleggingsblad leest ze dat er een technische trendomslag in de markt aan zit te komen, en dat het nu een goed moment is om in te stappen. Ze ontvangt ook nog goede raad van de adviseur van haar bank die betoogt dat de "Hout en Papier" sector al langdurig ondergewaardeerd is. Vervolgens belooft men haar gouden bergen met moderne financiële instrumenten zoals opties. Renate studeert hard, en ontdekt al snel dat deze adviezen haar helaas niet gegarandeerd de weg wijzen naar snelle rijkdom. In de taak over ethische aspecten van het vak luistert zij tenslotte een zakelijk gesprek van haar vader af die directeur van een grote onderneming is, en op het punt staat een ander bedrijf over te nemen. Uit de woorden van haar vader leidt zij af dat de koers van het doelwit van de overname vrijwel zeker zal gaan stijgen, zodra het nieuws van de overname publiekelijk bekend wordt. Zij koopt snel enige aandelen. Renate concludeert dat je meer moet weten dan alle anderen om koersen te kunnen voorspellen.

Renate's frustratie is gelijk aan die van vrijwel iedereen die voor het eerst met de efficiënte markt hypothese kennis maakt. Veranderingen in aandelenkoersen zijn bijna niet te voorspellen, juist omdat iedereen dat zo goed mogelijk tracht te doen. Dit is de typische logica van een financieel econoom, en is vaak moeilijk uit te leggen aan studenten. Samuelson (1965) verwoordt de hypothese in de titel van een artikel als "Proof that properly anticipated prices fluctuate randomly". McCloskey (1997) zegt het bloemrijker:' 


\begin{abstract}
"De ambitie om te voorspellen en te besturen is economisch gezien misplaatst, vanwege economische principes die door iedere econoom onderschreven worden. (...) Als iemand je een gouden beurstip geeft, wat denk je dan? Als je verstandig bent, en burgerlijk, dus geen romantische aristocraat of onnozele boer, dan zeg je bij jezelf, 'Waarom vertelt hij me dit? Waarom volgt hij zijn eigen advies niet op?' Je stelt de Amerikaanse vraag: 'Als hij het zo goed weet, waarom is hij dan niet rijk?'
\end{abstract}

Drie typen voorspellingen

In het blok Empirische Analyse van Financiële Markten worden studenten uitgenodigd zelf koersen te voorspellen om zo de kracht van de efficiënte markt hypothese zelf te ontdekken. $\mathrm{Zij}$ verdiepen zich in drie manieren van voorspellen van rendementen. Die typering is afkomstig van Fama (1991), de grondlegger van modern empirisch onderzoek naar de efficiënte markt hypothese.

Het meest bekende type voorspellingen zijn tijdreeksvoorspellingen. Gegeven informatie uit het verleden, wat zal de koers van het aandeel Philips morgen doen? Wat zijn de verwachtingen voor het komend jaar, wat voor de verre toekomst? Een voorbeeld van dit type voorspellingen is de technische analyse waar Renate in eerste instantie mee geconfronteerd wordt. Op basis van het koersverloop uit het recente verleden voorspelt het beleggingsblad Renate een trendomslag.

De onderwaardering van de sector "Hout en Papier" is een crosssectionele voorspelling, beter gezegd een relatieve voorspelling in de terminologie van Cochrane (1998), of een voorwaardelijke voorspelling in het jargon van econometristen. Bij cross-sectionele voorspellingen staat niet voorop wat we denken dat het aandeel Philips zal gaan doen, maar meer de vraag of Philips het beter zal doen dan KLM. Een ander voorbeeld van relatief voorspellen is de waardering van opties. De waarde van het onderliggende aandeel wordt daarbij als gegeven beschouwd. Cross sectioneel voorspellen is makkelijker dan het doen 
van tijdreeksvoorspellingen. Het is eenvoudiger om iets over de koers van Philips te zeggen als we weten wat de markt als geheel gedaan heeft. Hoe de prijs van een call optie Philips morgen zal veranderen, is minder moeilijk gegeven de koersverandering van Philips aandelen. Veel van de grote successen van financiële economie hebben betrekking op het relatief makkelijke probleem van relatief voorspellen.

Een derde soort voorspellingen zijn "event studies". Bij tijdreeksvoorspellingen doen we op elk moment een uitspraak omtrent het verwachte rendement in een komende periode. Bij "event studies" willen we niet op elk moment een voorspelling doen, maar alleen op die momenten dat er iets te voorspellen valt. Als er geen nieuws is omtrent een onderneming, is er ook geen reden onze mening omtrent dat aandeel te herzien, en valt er daarom weinig te voorspellen. Er breken pas interessante tijden aan als een onderneming kwartaalcijfers bekend maakt, of wanneer er bijvoorbeeld fusieplannen aangekondigd worden zoals in het telefoongesprek van Renate's vader. In een "event" studie onderzoeken we het typische koersverloop rond het tijdstip van een belangrijke gebeurtenis. Onder de efficiënte markt hypothese zou het nieuws vrijwel onmiddellijk in de koers verwerkt moeten zijn.

\section{Efficiëntie en econometrie}

In het begin van de jaren dertig verrichtte Alfred Cowles het eerste grootschalige onderzoek naar de voorspelbaarheid van beurskoersen. ${ }^{2}$ Door dit onderzoek kwam Cowles in aanraking met de toen pas opgerichte Econometric Society. In 1932 richtte hij de Cowles Commission op, die later verantwoordelijk zou zijn voor grote doorbraken in de econometrie. Op die manier is er al sinds de beginjaren van de econometrie een sterke band tussen financiering en econometrie. De ontwikkeling van de econometrie is daardoor indirect geholpen door de zoektocht naar voorspelbaarheid van aandelenkoersen. Omgekeerd heeft de econometrie weinig bijgedragen aan het vinden van een voorspelformule. In een artikel in de eerste jaargang van Econometrica in 1933 beantwoordde Cowles de vraag: "Can Stock Market Forecasters Forecast?" met: Het is twijfelachtig. 


\section{Persistentie}

De efficiënte markthypothese stelt dat koersen alleen reageren op nieuws, en dat daardoor koersveranderingen onvoorspelbaar zijn. Maar het maakt wel uit hoe dat nieuws geïnterpreteerd moet worden. Wat betekent het als een onderneming een jaar onverwacht minder winst maakt? Dat zal er van af hangen of de markt verwacht dat de winst slechts tijdelijk laag is, en zich in de toekomst weer zal herstellen, of dat men denkt dat de winstdaling permanent is. Bij een tijdelijke schok zal de koersreactie minder heftig zijn dan bij een permanente schok. De persistentie van de schok bepaalt de omvang van de koersreactie. Het begrip persistentie is daarom belangrijk voor het begrijpen van koersfluctuaties.

Voordat ik meer over persistentie ga zeggen, zal ik eerst een aantal typische kenmerken van rendementen de revue laten passeren. Ter illustratie gebruik ik prijzen en rendementen van Nederlandse aandelen.

\section{Voorbeeld 1: Gemiddeld rendement op aandelen}

Het voorspellen van rendementen kan niet makkelijk zijn. Alleen al de vraag wat het gemiddeld rendement op aandelen is, valt niet nauwkeurig te beantwoorden. Figuur 1 laat jaarlijkse rendementen voor de Nederlandse beursindex zien voor de periode 1946 tot en met 1996. Het gemiddelde jaarlijkse rendement over de gehele periode van 50 jaar is $11 \%$. De jaarlijkse standaarddeviatie is $18 \%$. Dit betekent dat de standaardfout van het gemiddelde rendement gelijk is aan $18 / \sqrt{ } 50=$ $2.5 \%$. Een $95 \%$ betrouwbaarheidsinterval voor het gemiddelde heeft een grootte van $4 \times 2.5=10 \%$. Fluctuaties in het rendement zijn zo groot dat we met 50 jaar data niet meer kunnen zeggen dan dat het gemiddelde rendement ergens tussen de zes en zestien procent ligt. 


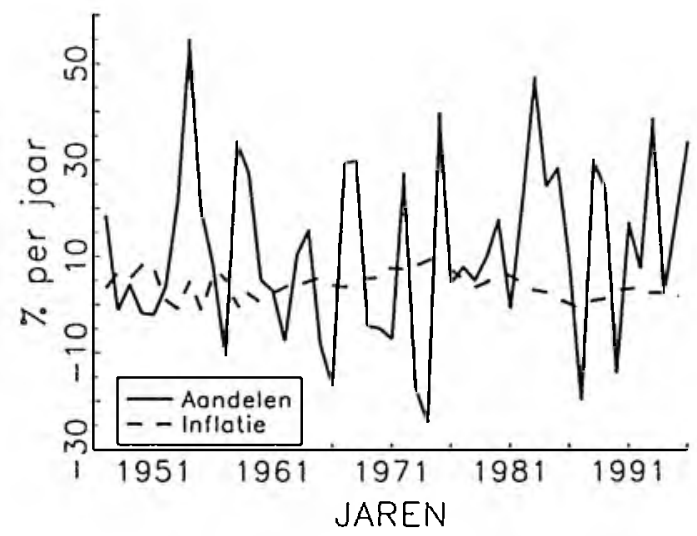

Figuur 1: Jaarlijkse rendement op aandelen en inflatie De figuur laat het jaarlijkse rendement zien van de $\mathrm{MSCl}$ Nederland index, en de jaarlijkse inflatie in Nederland op basis van de consumenten prijsindex. Rendementen zijn berekend als logarithmische veranderingen

De situatie wordt natuurlijk alleen maar erger, wanneer we de mogelijkheid openen dat het verwachte rendement niet in alle decennia gelijk is. In de woorden van Fischer Black (1986):

"We kunnen bijvoorbeeld niet weten wat het verwachte rendement op de markt is. Er is alle reden om aan te nemen dat het over de tijd verandert, en geen speciale reden om te geloven dat de veranderingen geleidelijk zullen zijn." De conclusie van Black is dat het hierdoor moeilijk is om theorieën die iets over het verloop van koersen zeggen wetenschappelijk te toetsen. Deze conclusie vormt een uitdaging aan financiële econometrie. ${ }^{3}$ -

Voorbeeld 2: (Te) hoge volatiliteit.

De reden dat we het gemiddelde rendement niet goed kunnen bepalen is dat koersen zo wispelturig zijn. Die wispelturigheid noemen we volatiliteit. De hoge volatiliteit is nog veel duidelijker als we naar dagelijkse fluctuaties kijken. Dagelijks zien we koersen met gemiddeld meer dan een procent op en neer gaan. Figuur 2 laat bijvoorbeeld de dagelijkse rendementen op de Nederlandse marktindex over een periode 
van vier jaar zien. Een dergelijk patroon is typisch voor alle aandelen en elke historische periode.

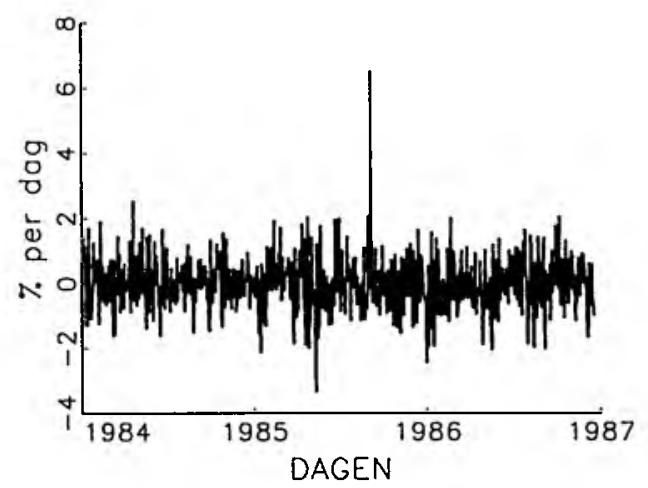

Figuur 2: Dagelijkse rendement van aandelen

De figuur laat dagelijkse logaritmische veranderingen van de Nederlandse EOE index zien voor de periode januari 1984 tot en met september 1987.

Hoe kan een dergelijke variabiliteit ooit rationeel verklaard worden door nieuws omtrent de waarde van een bedrijf? Moeten vooruitzichten van bedrijven zich dan niet zeer sterk wijzigen van dag tot dag? Het lijkt erop dat de omvang van de koersfluctuaties van aandelen op geen enkele wijze te rechtvaardigen is binnen de efficiënte markthypothese. In de ogen van Shiller (1981) is de variabiliteit van koersen excessief ten opzichte van het fundamentele nieuws omtrent dividenden en winsten. Maar voordat we kunnen zeggen of iets excessief is, moeten we eerst definiëren wat normaal is. Hoe beweeglijk kunnen we verwachten dat koersen op een efficiënte markt zullen zijn? Daarvoor hebben we een waarderingsmodel nodig.

\section{Voorbeeld 3: Dividend Groei Model}

Over de grondslag voor de waarde van een aandeel bestaat nauwelijks discussie. Cochrane (1998) legt uit dat elk waarderingsprobleem altijd te herleiden is tot de verwachte contante waarde formule.

Stelling: De waarde van een aandeel $\left(P_{0}\right)$ is gelijk aan de verwachte verdisconteerde stroom van toekomstige dividenden $\left(D_{i}\right)$. 
Kortweg noemen we de verdisconteerde stroom van toekomstige dividenden ook wel de contante waarde van dividenden. Om de waarde van een aandeel te kunnen uitrekenen moeten we dus een voorspelling maken van wat dat aandeel in de toekomst aan dividenden zal opbrengen, en daar beginnen de meningsverschillen. De eenvoudigste veronderstellingen zijn dat dividenden zullen groeien met een vast percentage $g$, en dat de disconteringsvoet een constante is. In dat geval krijgen we een waarderingsformule die bekend staat als het dividendgroei model, en die in elk elementair tekstboek is terug te vinden:

$$
r=\frac{D_{1}}{P_{0}}+g
$$

Het totale rendement $r$ bestaat uit twee delen: dividend rendement $D_{1} / P_{0}$ en de toekomstige groeimogelijkheden $g$ van de onderneming.

Laten we eens een rekenvoorbeeld nemen. Stel dat op dit moment de koers $P_{0}=100$ is. Het eerstvolgende dividend is $D_{1}=3$, dat wil zeggen het dividendrendement bedraagt $3 \%$, hetgeen overeenkomt met het gemiddelde in Nederland. Dividend rendement is immers maar een klein gedeelte van het rendement op aandelen. Koerswinsten zijn omvangrijker. Stel nu dat om wat voor reden dan ook beleggers opeens genoegen nemen met een totaal rendement dat anderhalf procent minder is dan voorheen. Als $r$ met anderhalf procent daalt, en $D_{1}$ en $g$ niet veranderen, moet de beurskoers $P_{0}$ zich wel aanpassen, en wel tot $P_{0}=200$. Ten opzichte van de beginsituatie is de koers in één keer verdubbeld. De recente verdubbeling van de Nederlandse beursindex in korte tijd zou dus uitgelegd kunnen worden als een kennelijke kleine daling van het geëiste rendement. Een kleine verandering in het geëiste rendement kan dus desastreuze gevolgen hebben voor de koers, als schokken een permanent karakter hebben. ${ }^{4}$ Uit dit voorbeeld blijkt ook dat beurskoersen buitengewoon variabel kunnen zijn. Als veranderingen persistent zijn, is hoge volatiliteit niet in tegenspraak met de efficiënte markthypothese. 


\section{Een vlinder in China}

Financiële data lijken op het eerste gezicht sterk op realisaties van een chaotisch proces. Chaostheorie is een tijd lang populair geweest als een model om het gedrag van aandelenkoersen te beschrijven met behulp van deterministische niet-lineaire vergelijkingen. Een chaotisch proces is extreem gevoelig voor beginvoorwaarden. Een veel gebruikt voorbeeld is een vlindertje dat luchtstromingen in beweging zet ergens in China, waaruit later stormen ontstaan, en dat uiteindelijk zelfs een beurskrach veroorzaakt.

De populariteit van chaosmodellen is niet vreemd. Net als voor een chaotische tijdreeks vinden we voor financiële data dat:

- prijzen gevoelig zijn voor kleine schokken,

- modellen erg gevoelig zijn voor kleine veranderingen in de parameters,

- signalen zwak zijn ten opzichte van de ruis (ik zal dit in latere voorbeelden uitleggen),

- een maatstaf als het gemiddelde uiterst instabiel is,

- de voorspelbaarheid snel afneemt met de voorspelhorizon.

Bovenstaande eigenschappen ontleen ik aan Bernstein's (1996) geschiedenis van de statistiek in relatie tot financiële markten. In tegenstelling tot de natuurwetenschappen is er echter nauwelijks een economisch overtuigend model voorhanden dat chaotische dynamiek ten gevolge heeft. Vorst (1989) is in zijn oratie aan de Erasmus universiteit al eens uitvoerig ingegaan op de onterechte populariteit van chaos theorie. Middels de voorbeelden in deze rede hoop ik te laten zien dat economische theorie ook zeer goed in staat is om te verklaren waarom op zich kleine gebeurtenissen grote gevolgen kunnen hebben. Het hoeft niet noodzakelijk een teken van beursgekte te zijn, en het hoeft ook niets met natuurverschijnselen die buiten onze macht liggen, te maken te hebben, wanneer een op zichzelf klein nieuwsfeit als een gerucht over een daling in de rente de koersen flink doet stijgen.

Wanneer prijsvorming voor lange termijn financiële contracten plaatsvindt in een efficiënte markt, zal het prijsverloop overeenkomsten vertonen met elementen uit chaostheorie. Een noodzakelijke voorwaarde 
is wel dat de onderliggende economische processen waarop deze financiële contracten betrekking hebben persistent zijn. Overal waar persistentie een rol speelt, zullen we deze verschijnselen tegen komen. En dat geldt voor vrijwel ieder probleem in de financiële economie, waarin lange termijn overwegingen belangrijk zijn.

Voorbeeld 4: Zijn beleggers kortzichtig?

In populaire discussies wordt vaak de indruk gewekt dat beleggers alleen maar op korte termijn winsten uit zijn. Lange termijn denken wordt niet onmiddellijk geassocieerd met het zogenaamde snelle geld op de beurs. Een bedrijf dat veel rekening houdt met de aandeelhouders wordt verweten dat het te weinig aan de lange termijn denkt. Toch is het een misvatting dat korte termijn winsten niet tot stand komen op basis van lange termijn overwegingen.

Het rendement over elke periode is de som van de koerswinst en eventueel uitgekeerde dividenden. Koerswinst is het verschil tussen aanen verkoopprijs van een aandeel. De koers van een aandeel vandaag, wordt bepaald door de verwachte prijs van dat aandeel morgen. Maar de prijs morgen wordt weer bepaald door de verwachte prijs overmorgen, enzovoort. Om die reden spelen lange termijn overwegingen direct een rol. Uiteindelijk komen we weer uit bij het dividendgroei model, waarin de koers van een aandeel gelijk is aan de contante waarde van alle toekomstige verwachte dividenden.

Tot nu toe veronderstelde ik dat het geëiste rendement permanent met één procent toenam. Die oneindige persistentie is natuurlijk absurd. Veel redelijker is een model waarbij het rendement met lange golven rond een bepaald gemiddelde schommelt. Campbell, Lo en MacKinlay (1997) schatten dat veranderingen in het geëiste rendement een halfwaardetijd van acht jaar hebben. Op basis daarvan berekenen zij dat een daling in het verwachte rendement met één procent een stijging van de koers met twaalf procent ten gevolge heeft. Dat is ruim minder dan in voorbeeld 3, maar nog steeds substantieel. Tabel 1 geeft de koersverandering bij verschillende waarden voor de persistentie. 
Tabel 1: Persistentie en koersgevoeligheid

\begin{tabular}{l|ccccc}
\hline Persistentie (halfwaardetijd in jaren) & 1 & 2 & 4 & 8 & 32 \\
\hline $\begin{array}{l}\text { Koersverandering bij één procent } \\
\text { daling in het verwachte rendement }\end{array}$ & 2.0 & 3.4 & 6.3 & 12.0 & 46.7 \\
\hline
\end{tabular}

Berekeningen zijn gebaseerd op formule (7.1.29) in Campbell, Lo en MacKinlay (1997).

\section{Aandelen en inflatie}

Nu we hebben gezien dat persistentie een belangrijke rol speelt bij het begrijpen van bewegingen van aandelenkoersen, wordt het tijd nader in te gaan op de vraag waarom het verwachte rendement zich zal bewegen in lange persistente golven. Daarvoor worden in de literatuur twee standaard redenen genoemd. De eerste heeft te maken met risico. Meer risico betekent dat beleggers een hoger rendement eisen. Het risico van de aandelenmarkt wordt vaak gemeten met behulp van de variantie van de koersveranderingen. Hoe meer de koersen fluctueren, des te hoger is het risico. Uit econometrisch onderzoek is gebleken dat de variantie een persistent proces volgt, en daarmee is dit een plausibele verklaring. Nijman (1993) heeft hier in zijn oratie in Tilburg uitgebreid over gesproken.

De tweede reden is inflatie. Tot nu toe heb ik impliciet gesproken over het nominale rendement op aandelen. De meer interessante vraag is hoe het reële rendement zich gedraagt. Bij het nominale rendement vergelijken we guldens vandaag met guldens in de toekomst. Bij het reële rendement gaat het om de koopkracht van die toekomstige guldens. Reële rendementen lijken op het eerste gezicht niet anders dan nominale. In figuur 1 lijken de fluctuaties in inflatie verwaarloosbaar ten opzichte van maandelijkse nominale rendementen. Het lijkt weinig uit te maken of we veronderstellen dat het verwachte nominale rendement constant is, of dat het verwachte reële rendement constant is. In voorbeeld 1 hebben we al geconstateerd dat het gemiddelde rendement hoe dan ook 
onnauwkeurig geschat wordt vanwege de grote variantie van rendementen.

Inflatie heeft de typische eigenschappen van een persistente tijdreeks. De maandelijkse fluctuaties zijn klein, maar als inflatie eenmaal hoog is, dan blijft het dat ook meestal jarenlang.

\section{Voorbeeld 5: Pensioenfondsverplichtingen}

De belegging van pensioengelden is een populair thema bij oraties. ${ }^{5}$ Dat is niet zo verwonderlijk vanwege zowel eigenbelang als ook de grote vermogens die door pensioenfondsen worden beheerd. Ook ik wil hier via dit voorbeeld dieper op ingaan. In empirische studies is vaak gekeken naar de relatie tussen nominale rendementen en inflatie. Pensioenfondsen hebben er bijvoorbeeld alle belang bij hun beleggingen zodanig te kiezen dat zij maximaal beschermd zijn tegen inflatie. De verplichtingen van pensioenfondsen zijn vaak waarde- of welvaartsvast, dat wil zeggen gekoppeld aan een index voor prijzen of lonen. De beleggingshorizon van pensioenfondsen is ook lang. Pensioenrechten worden over een periode van vaak 40 jaar opgebouwd, terwijl men er daarna toch ook nog eens minimaal tien jaar van hoopt te genieten. Inflatie is daarmee een lange termijn risico voor pensioenfondsen.

In hoeverre biedt beleggen in aandelen een goede bescherming tegen het lange termijn inflatierisico? Om dat te analyseren hebben we een klein model nodig. Ik ga uit van de volgende veronderstellingen:

- Op korte termijn is er een negatief verband tussen inflatie en rendement. Een onverwachte stijging van inflatie is slecht nieuws voor aandelen.

- Het geëiste reële rendement van aandelen is in elke periode gelijk.

- Inflatieschokken zijn persistent. Dat betekent dat er langdurige perioden zijn met hoge inflatie zoals in de jaren zeventig, afgewisseld met lange perioden met lage inflatie zoals momenteel. 
Het formele model waarop de analyse is gebaseerd luidt:

$$
\begin{aligned}
& R_{t}=c+E_{t-1}\left[\Pi_{t}\right]+e_{t} \\
& \Pi_{t}=\mu+\alpha\left(\pi_{t-1}-\mu\right)+\eta_{t} \\
& e_{t}=\delta \eta_{t}+\epsilon_{t},
\end{aligned}
$$

waarbij $R$ het nominale rendement op aandelen is, $\pi$ de inflatie is, $\alpha$ de persistentie van inflatieschokken meet, en $\delta$ het directe effect van inflatie op aandelenrendement weergeeft. De inflatieschok $\eta$ is ongecorreleerd met de specifieke rendementsschok $€$. Parameters zijn gecalibreerd op jaarlijkse data voor Nederland voor de periode 1947-1996:

\begin{tabular}{ccc}
\hline$\sigma_{c}$ & $\sigma_{0}$ & $\delta$ \\
\hline $17 \%$ & $2 \%$ & -1.6 \\
\hline
\end{tabular}

De hedge ratio in figuur 3 is gedefinieerd als

$$
\Delta_{k}=\frac{\operatorname{Cov}\left(R_{l+k}^{(k)}, \Pi_{l+k}^{(k)}\right)}{\operatorname{Var}\left(R_{l+k}^{(k)}\right)},
$$

waarbij $R_{t+k}^{(k)}$ het rendement over $k$ perioden is, $\Pi_{l+k}^{(k)}$ de inflatie over kperioden is. In figuren 3 en 4 is $\alpha=1$ verondersteld. Figuur 5 laat de limiet voor $k \rightarrow \infty$ zien voor verschillende waarden van $\alpha$. De halfwaardetijd is $-\ln (2) / \ln (\alpha)$.

Voor elk van deze aannames is empirisch bewijs. ${ }^{6}$ Wegens de korte termijn negatieve relatie is vaak in de literatuur geconcludeerd dat aandelen geen goede bescherming tegen inflatie bieden. Hierbij wordt echter onvoldoende rekening gehouden met de persistentie van inflatie. Een positieve schok in inflatie heeft een eenmalig negatief effect op het rendement op aandelen, maar doordat het geëiste rendement ook stijgt, heeft de schok in alle volgende perioden een positief effect op het rendement. Aandelen bieden op korte termijn weliswaar geen bescherming tegen inflatie, maar op lange termijn des te meer. 
1 JAAR

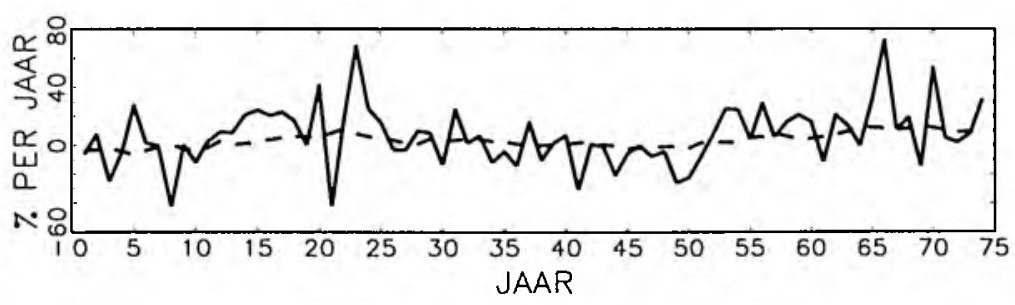

10 JAAR

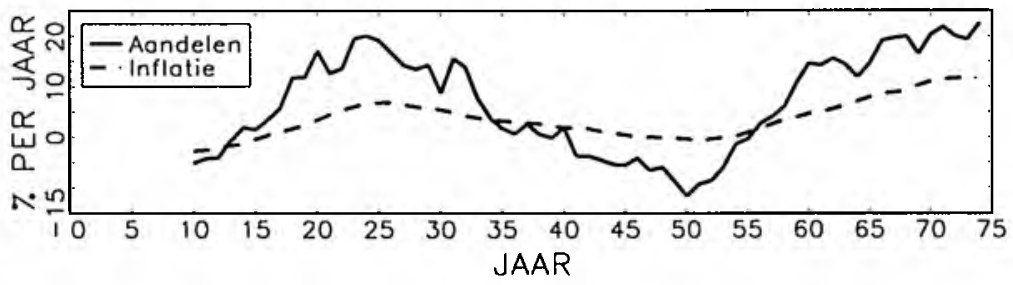

Figuur 3: Rendement op aandelen en inflatie

De figuur laat gesimuleerde tijdreeksen zien volgens het model in voorbeeld 5 . Het venwachte reële rendement is constant, inflatieschokken zijn permanent en onverwachte inflatie heeft een negatief direct effect op aandelen.

Figuur 3 illustreert dit voor gesimuleerde gegevens met het beschreven model. In het bovenste paneel zijn maandelijkse schokken in inflatie en aandelenrendement uitgezet. Hier is geen enkel verband te zien. De volgende grafiek beschouwt schokken over een horizon van tien jaar. Hier is duidelijk een positief verband te onderscheiden. Inflatie is een langzaam slopende ziekte. Als prijzen dit jaar met een procent meer stijgen dan verwacht moeten we rekening houden met dezelfde extra stijging volgend jaar. Dat is cumulatief al twee procent. Het effect van een tegenvaller op de beurs is geheel anders. Als het dit jaar tegenzit, zegt dat niets over wat er volgend jaar gaat gebeuren. Volgens de efficiënte markthypothese is ieder jaar weer nieuw. Hier treedt geen cumulatie van schokken op. 
Op basis van dit model kunnen we berekenen over welke horizon aandelenrendement en inflatie een positieve correlatie zullen vertonen.? Die correlatie bepaalt mede of aandelen een aantrekkelijke beleggingsvorm zijn voor een pensioenfonds. De resultaten zijn weergegeven in figuur 4 in de vorm van de zogenaamde 'hedge ratio'. De 'hedge ratio' is het gedeelte van het vermogen dat een fonds in aandelen zou moeten beleggen om het reële risico te minimaliseren. Daarbij veronderstel ik in dit voorbeeld gemakshalve dat het fonds slechts kan kiezen uit aandelen en nominaal risicovrije beleggingen. Tot vijf jaar domineren het negatieve directe effect van inflatie en het hoge specifieke risico van aandelen. Als het pensioenfonds slechts een horizon van vijf jaar heeft, dan zal men bij risicomijdend gedrag niet veel in aandelen beleggen. Over een periode van tien jaar is het belang van aandelen al opgelopen tot 35 procent van de portefeuille. Als de beleggingshorizon 25 jaar is, wordt dat 80 procent. Uiteindelijk gaat het gewicht van aandelen naar 100 procent, omdat aandelen op lange termijn goede bescherming tegen inflatierisico bieden.

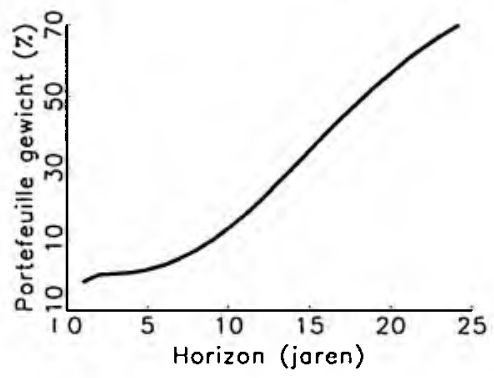

Figuur 4: Inflatiebestendigheid van aandelen

De figuur laat zien dat bij een langere beleggingshorizon een groter deel van het vermogen in aandelen (het portefeuille-gewicht van aandelen) wordt belegd. De doelstelling is het reële risico te minimaliseren. De keuze is beperkt tot aandelen en een nominaal risicovrij object.

De resultaten zijn uiterst gevoelig voor de mate van persistentie van inflatie. Dat is wat dit model gemeen heeft met chaostheorie. Figuur 5 laat het relatieve belang van inflatieschokken zien als functie van de mate van persistentie. Bij een halfwaardetijd van inflatie van 5 jaar bieden aandelen slechts weinig bescherming, en bijgevolg is het lange termijn gewicht van aandelen in de portefeuille slechts 25 procent. Bij meer persistentie, dat wil zeggen hogere halfwaardetijden, neemt het belang van inflatie snel toe tot 100 procent in de limiet. Het is daarom 
belangrijk om een goede schatting van de persistentie van inflatieschokken te hebben.

Natuurlijk is dit een grove vereenvoudiging van het beleggingsprobleem van een pensioenfonds. Daarvoor zijn gedetailleerde asset/ liability management modellen ontwikkeld. Ik wil met het voorbeeld echter laten zien dat de economische inputs voor dit soort ALM studies minstens even belangrijk zijn. Behalve gedetailleerd inzicht in de verplichtingen van een pensioenfonds, is het ook noodzakelijk de economische relatie tussen beleggingen en verplichtingen, zoals tussen aandelenrendement en inflatie, goed te modelleren.

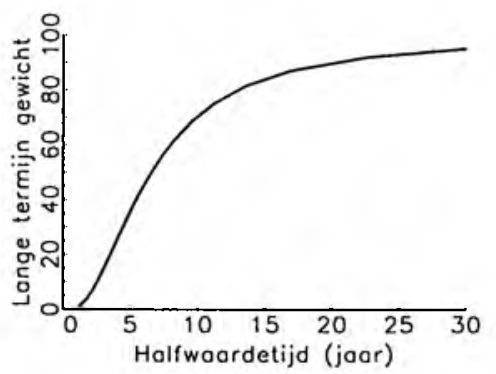

Figuur 5: Inflatie-persistentie en de vraag naar aandelen.

De figuur laat zien dat naarmate de persistentie van inflatieschokken toeneemt, het gewicht van aandelen ook toeneemt in een portefeuille die het lange termijn reële risico minimaliseert.

\section{Andere voorbeelden van persistentie}

Persistentie is de cruciale parameter bij veel meer problemen in de beleggingsleer. De contante waarde formule gaat uit van toekomstige verwachte dividenden. Die dividenden passen zich op hun beurt vaak langzaam aan aan de winsten van een onderneming. Persistentie bepaalt hoe sterk onverwachte veranderingen in winst of dividend doorwerken in de koers.

\section{Voorbeeld 6: De "kerstboom"}

Recent is er veel aandacht voor het verschil tussen zogenaamde "groei" aandelen en "waarde" aandelen. We spreken over een groei-aandeel als de koers hoog is ten opzichte van de winst. Voor waarde-aandelen 
geldt het omgekeerde. Een waarde-aandeel is het aandeel van een bedrijf waarvoor de koers/winst verhouding laag is. Populair gezegd: het is een koopje. Vaak keert een dergelijk "waarde" bedrijf ook veel winst uit aan de aandeelhouders, zodat het dividend hoog is.

Waarom kan de koers van een bedrijf dat weinig winst maakt toch hoog zijn? Alleen als de markt verwacht dat dat bedrijf in de toekomst sterk zal groeien; in ieder geval sneller dan bedrijven met een lagere koerswinst verhouding. Beleggers zijn bereid een hoge prijs te betalen voor een aandeel als zij verwachten dat de winst in de toekomst hoog zal zijn. Persistentie in het verschil in winstgroei is hetgeen de verschillen in koers/winst verhoudingen tussen bedrijven moet verklaren. In zijn provocerende boek The New Finance met als ondertitel "The case against efficient markets" betoogt Haugen (1995) dat het verschil tussen winstgroei van waarde- en groei-aandelen onvoldoende persistent is om het prijsverschil tussen deze aandelen te rechtvaardigen. Hoewel bedrijven met een hoge koers/winst verhouding de eerstkomende paar jaar gemiddeld sneller groeien dan een gemiddeld bedrijf, kunnen ze deze groei onvoldoende lang bestendigen. ${ }^{8}$ Haugen geeft een aantal berekeningen waaruit moet blijken dat "groei"-aandelen zwaar overgewaardeerd zijn.

Als altijd zijn berekeningen waarin persistentie een rol speelt echter uiterst gevoelig voor de aannames. We disconteren immers de verwachte kasstroom van een onderneming waarvan we veronderstellen dat die oneindig lang zal blijven bestaan. Bovendien veronderstellen we dat de winst - of het nu een groei- of een waarde-aandeel is - tot in lengte van dagen zal blijven groeien.

De gevoeligheid voor de veronderstellingen neemt niet weg dat waardeaandelen historisch gezien beter hebben gepresteerd dan groei aandelen volgens veel empirisch onderzoek. Toch is het goed nog eens terug te verwijzen naar voorbeeld 1 . Zo nauwkeurig kennen we gemiddelde rendementen niet. 
Voorbeeld 7: De vega van een optie

Persistentie komt in vrijwel elke toepassing terug. Hier volgt een voorbeeld met opties. Scholes en Merton hebben afgelopen jaar de Nobelprijs ontvangen voor één van de meest precieze formules binnen de economische wetenschappen. De Black-Scholes formule voor de waarde van een optie is misschien wel de enige vergelijking die het ooit tot de voorpagina van een krant heeft gebracht. De waarde van een optie, i.e. het recht om tegen een vooraf vastgestelde prijs en binnen een vastgestelde periode een bepaald aandeel te kopen of verkopen, is een functie van slechts één enkele onbekende parameter, namelijk de volatiliteit van het aandeel. Daarmee is de waarde van een optie heel precies uit te rekenen, relatief ten opzichte van de huidige koers van het aandeel.

Een belangrijke aanname is dat de volatiliteit van het aandeel niet verandert in de loop van de tijd. Het effect van een verandering van de volatiliteit van een optie wordt in de optie literatuur aangegeven met vega. Aangezien de Black-Scholes formule is afgeleid onder de veronderstelling dat de volatiliteit constant is over de looptijd van de optie, wordt met verandering in volatiliteit een permanente verandering bedoelt. Als de verandering in de volatiliteit in werkelijkheid tijdelijk is, dan leidt differentieren van de Black-Scholes formule tot overschatting van de verandering in de optieprijs.

In werkelijkheid vertoont volatiliteit de eigenschappen van een persistente tijdreeks. Er zijn af wisselend periodes met weinig beweeglijkheid in rendementen en periodes waarin de rendementen zich wispelturig gedragen. ${ }^{10}$ De waarde van een optie, en vooral de nauwkeurigheid waarmee die bepaald kan worden, kunnen dan zeer gevoelig zijn voor de persistentie van de volatiliteit. In sommige gevallen vonden Mahieu en Schotman (1998) dat een $95 \%$ betrouwbaarheidsinterval zo groot is dat de optie makkelijk het dubbele of de helft van de berekende waarde kan zijn. Een kleine schattingsfout kan dan grote gevolgen hebben." 
Natuurlijk kunnen we de waarde van een optie veel nauwkeuriger bepalen wanneer we ook gebruik maken van de prijzen van andere verhandelde opties. Dat is een vorm van relatief voorspellen. Van hoe meer financiële titels we de prijzen op de markt direct kunnen waarnemen, des te makkelijker wordt het om een prijs te bepalen voor een nieuw instrument dat daar veel op lijkt. Omgekeerd kunnen we uit de marktprijs van opties veel leren hoe de markt de persistentie van de volatiliteit blijkbaar inschat. De markt is met een prijs voor de optie gekomen, en heeft dus ook het moeilijke probleem moeten oplossen om de toekomstige volatiliteit te schatten. Uit de tot stand gekomen prijzen kunnen we dan afleiden welke mate van persistentie daarmee in overeenstemming is. Hiermee loop ik vooruit op het econometrische deel van deze rede.

\section{Voorbeeld 8: Wisselkoersen en renteverschillen}

Wisselkoersen behoren tot de meest volatiele financiële prijzen. Een deel van de verklaring is de persistentie van renteverschillen tussen landen. Beleggers zullen geneigd zijn hun kapitaal aan te houden in het land waar de rente het hoogst is. Een hoge rente betekent een grote kapitaalinstroom, waardoor de wisselkoers zal stijgen tot een zo hoog niveau dat het renteverschil gecompenseerd wordt door de verwachte toekomstige daling van de wisselkoers. Deze relatie staat bekend als ongedekte interest-pariteit. Maar die toekomstige wisselkoers wordt weer bepaald door het toekomstige verwachte renteverschil. Net als voor de contante waarde formule voor aandelen, volgt uiteindelijk dat de wisselkoers gelijk is aan de som van toekomstige verwachte renteverschillen. Omdat het cumulatie effect weer optreedt, is persistentie van renteverschillen de cruciale parameter. Een kleine renteverandering door een centrale bank kan tot felle reacties op de valutamarkten leiden.

\section{Voorbeeld 9: Permanente Inkomenshypothese}

Het oudste en meest bekende voorbeeld van het belang van persistentie is de permanente inkomenshypothese als bouwsteen voor de theorie van consumentengedrag. Volgens de PIH, ontwikkeld door Friedman 
(1957), proberen mensen hun consumptie over de tijd uit te smeren. Als het inkomen nu laag is, maar men in de toekomst een hoger inkomen verwacht, is het nuttig om nu geld te lenen. Een implicatie van de theorie is dat mensen nauwelijks hun consumptiegedrag zullen veranderen als gevolg van een tijdelijke inkomensschok. Macro-economisch verwachten we dat consumptie veel minder fluctueert dan inkomen. De volatiliteit van consumptieveranderingen zal groter zijn naarmate de persistentie van de inkomensverandering groter is.

Toetsen van de PIH kent een lange geschiedenis. Deaton (1992) geeft een breed overzicht van zowel de theoretische als ook de econometrische literatuur. Zijn conclusie (p. 81): "Het belangrijke punt is dat het effect van een schok in inkomen groter zal zijn naar mate die schok persistenter is."

\section{Voorbeeld 10: Termijnstructuur van de rente}

Het laatste voorbeeld ligt het dichtst bij mijn eigen onderzoek: het waarderen van vastrentende waarden en het beheersen van de risico's daarvan. Stel je kunt geld kort beleggen, zeg een jaar, tegen een rentepercentage van $5 \%$. Als alternatief kijkt je naar overheidsschuld met een looptijd van 10 jaar en een effectief rendement van $7 \%$. Wat is het gunstigst? Volgens de efficiënte markt hypothese is dat een domme vraag. Beide zijn natuurlijk gelijkwaardig, anders zouden de genoemde rentepercentages wel veranderen. Interessanter is de vraag waarom het rendement op langlopende leningen $7 \%$ is, terwijl voor kortlopende leningen slechts een percentage van $5 \%$ geldt. Hoe zal de lange termijn rente veranderen als de korte rente van $5 \%$ naar $6 \%$ gaat?

De verwachtingstheorie van de termijnstructuur geeft antwoord op deze vragen. Volgens de verwachtingstheorie neemt iemand nu genoegen met een lage rente voor kortlopende leningen, wanneer men verwacht dat de rente in de toekomst zal gaan stijgen. Als de rente stijgt, zal de waarde van de langlopende obligatie dalen. De korte termijn belegger kan dan na één jaar alsnog de langlopende obligatie goedkoop aanschaffen en op die manier profiteren van de gestegen rente. De 
verwachte rentestijging is precies zo groot dat beide alternatieven equivalent zijn.

Exacte berekeningen in de wereld van vastrentende waarden kunnen wiskundig gecompliceerd zijn. Maar alle termijnstructuur modellen stellen dat de lange rente bij benadering gelijk is aan het gemiddelde van de verwachte toekomstige korte rente. Aangezien lange termijn verwachtingen hier weer een rol spelen, is persistentie opnieuw de cruciale parameter. De rente is ook weer typisch een persistente tijdreeks, met langdurige perioden van lage of hoge waarden.

Rentetermijnstructuur modellen zijn vaak minder aansprekend vanwege het buitengewoon technische karakter ervan. Een bekende toepassing, waarin de theorie tot leven komt, is de waardering van hypotheken. Een hypotheeklening dient vaak als financiering van het eigen huis, waarbij dat huis als onderpand dient. Hypotheken zijn er in vele vormen. Meestal wordt er een vaste looptijd van dertig jaar afgesproken, vinden er vaste maandelijkse betalingen plaats en wordt de rente eens per vijf of tien jaar herzien. Tevens wordt het steeds gebruikelijker dat er verschillende opties ingebouwd zitten, zoals de mogelijkheid van gedeeltelijke vervroegde aflossing, een rentebedenktijd, het veranderen van een rentevast periode, enzovoort. Om deze opties op hun waarde te schatten, is een model nodig voor mogelijk toekomstige rente scenario's. Wanneer je besluit de rente voor tien vast te zetten, en vlak daarna daalt de rente, dan zit je met een nodeloos hoge last. In dat geval is de optie van vervroegd aflossen en herfinancieren waardevol. Wanneer de rente voor slechts korte tijd vast staat, bestaat het risico dat de rente stijgt, en langdurig hoog blijft, met bijkomend hoge lasten. Om de opties weloverwogen uit te oefenen, is de belangrijkste vraag vaak hoe lang de rente nog op het huidige niveau blijft en hoe groot de kans is dat de rente langdurig naar een ander niveau gaat. Daarmee is persistentie een belangrijke parameter bij het waarderen van hypotheek contracten, en bij het inschatten van de risico's. 
Persistentie komt bij rentemodellen op meerdere manieren naar voren. Eerst de mate waarin een verandering lange termijn gevolgen heeft. Daarnaast heeft rente nog de typische eigenschap dat de volatiliteit gerelateerd is aan het niveau van de rente. Als de rente laag is, zien we vaak ook slechts kleine veranderingen. Dat leidt er uiteindelijk toe dat de waarde van een hypotheek met vervroegde aflossingsopties extra gevoelig is voor de mate van persistentie. ${ }^{12}$

\section{Econometrie}

In het voorgaande heb ik laten zien dat persistentie een belangrijk begrip is voor problemen waarin lange termijn overwegingen een rol spelen. En dat zijn vrijwel alle problemen met betrekking tot prijzen op financiële markten. Ik wil nu verder gaan met het meten van persistentie. Wat heeft de econometrie op dit gebied te bieden?

Persistentie is het grote onderzoeksthema geweest in de tijdreekseconometrie sinds midden jaren tachtig. Nelson en Plosser (1982) hebben er als eersten op gewezen dat veel macro-economische tijdreeksen persistent lijken, en dat dit consequenties heeft voor de manier waarop we over macro-economische verschijnselen zoals de conjunctuurcyclus nadenken. De algemene indruk van hun onderzoek was, en is nog steeds, dat veel veranderingen in de economie structureel zijn. In de econometrische literatuur heeft het begrip cointegratie --dat is jargon voor de relatie tussen het trendmatige verloop in meerdere persistente reeksen -- een dominante invloed op het onderzoek gehad. $\mathrm{Er}$ is een veelheid aan statistische toetsen ontwikkeld uitgaande van de nulhypothese dat schokken een permanent effect hebben. Cochrane (1991) en anderen concludeerden echter al snel dat statistische methoden alléén nooit in staat zouden zijn om de mate van persistentie in een tijdreeks te bepalen.

Vanzelfsprekend is meten van persistentie een moeilijk probleem. We zien slechts één tijdreeks, en die zien we meestal over een beperkte lengte. Als we al eens naar lange historische reeksen van meer dan 
honderd jaar kijken, dan hebben we nog slechts tien onafhankelijke waarnemingen voor tien-jaars perioden. Tegelijk dient zich dan de vraag aan, of iets dat in 1900 gebeurd is, nog wel relevant is voor vandaag. Bestudering van dit soort lange tijdreeksen leert tevens dat niet elke schok even persistent is. Sommige grote schokken, zoals oorlogen, de oliecrisis in de jaren zeventig, en de val van de Berlijnse muur, hebben tot een totale verandering van het proces geleid. Nadat deze uitschieters weggenomen zijn, lijken de overige schokken veel minder persistent. ${ }^{13}$

Verfijning van technieken in tijdreeksanalyse zal ons niet verder helpen bij het meten van persistentie. Ongeacht hoe geavanceerd de statistische techniek is die we gebruiken, de schatting van de mate van persistentie is steeds terug te voeren op allerlei additionele veronderstellingen die in zo'n techniek ingebakken zitten. Ik ben het met Bomhoff (1994, p. 211) eens, wanneer hij stelt dat

"Teveel werk in macro economie is gemotiveerd door de wens om de nieuwste econometrische techniek toe te passen, in plaats van het zoeken naar statistische technieken waar theorie en data om vroegen."

Ik zou in deze uitspraak macro economie echter liever door financiering hebben vervangen.

\section{Financiële tijdreeksen}

Veel van de econometrische technieken zijn ontworpen voor toepassing op macro-economische tijdreeksen, zoals consumptieve bestedingen, nationaal inkomen, en prijsindices. De lange termijn samenhang tussen macro-economische tijdreeksen is vaak eenvoudig te zien. Consumptie en inkomen hebben bijvoorbeeld eenzelfde trendmatig verloop. We hebben dan ook niet eens erg lange tijdreeksen nodig om een significante relatie te ontdekken. Het gevaar bij macro-economische reeksen is eerder dat we te snel denken dat er een verband is. Tussen vrijwel alle variabelen vinden we wel iets, en we hebben de econometrische toetsen nodig om ons te vrijwaren van onzin-correlaties. 
Financiële tijdreeksen hebben echter andere eigenschappen. Figuur 1 liet bijvoorbeeld het nominale rendement op aandelen zien tezamen met inflatie. De grote volatiliteit van aandelen ontneemt het zicht op de onderliggende trend. In het voorbeeld was die trend echter precies dezelfde als de trend in inflatie. Maar zoals we in de voorbeelden 2 en 3 gezien hebben, is het de combinatie van persistentie in de fundamentele onderliggende economische variabelen, zoals inflatie, en efficiëntie van de aandelenmarkt waardoor de rendementen zo volatiel zijn. Het gevaar van onzin correlaties is hier klein. Dit is het grote verschil met macroeconomische reeksen. De rendementsreeksen hebben ook wel onderliggende trends, maar ze springen niet zo in het oog als bij de meeste macro-economische tijdreeksen. Dit soort data vereist andere econometrische technieken. Dat geldt niet alleen voor de relatie tussen inflatie en rendement, maar bijvoorbeeld ook voor veel studies naar veranderende risicopremies.

Dit is wellicht ook de reden dat moderne tijdreekseconometrie zoals toetsen op cointegratie maar mondjesmaat in de top financieringstijdschriften wordt toegepast, in ieder geval veel minder dan in de macroeconomische literatuur. In het recente handboek The Econometrics of Financial Markets van Campbell, Lo en MacKinlay (1997) wordt cointegratie pas op pagina 257 voor het eerst terloops genoemd. In het gehele 600 pagina's tellende boek komt het begrip slechts een paar keer voor. En dat is niet omdat persistentie niet belangrijk is. Integendeel, de auteurs hebben dan al veel aandacht geschonken aan lange termijn rendementen en lange termijn afhankelijkheid. De begrippen uit de tijdreeksanalyse worden voornamelijk gebruikt bij het ontwikkelen van modellen.

Financiële econometrie heeft zich ontwikkeld tot een zelfstandig vakgebied dat zich bezig houdt met het ontwikkelen van econometrische technieken die speciaal toegesneden zijn op de problemen van financiële reeksen. Veel is daarbij al bereikt, vooral met betrekking tot problemen die betrekking hebben op relatief voorspellen, dat wil zeggen de relaties tussen rendementen op verschillende activa. In deze rede heb ik echter 
voornamelijk gesproken over voorspellingen met een meer absoluut karakter. Die zijn een stuk moeilijker. Het meten van lange termijn relaties en persistentie zijn voldoende moeilijk dat daar nog veel te ontwikkelen valt.

\section{Panel data}

$\mathrm{Bij}$ het pensioenfondsen probleem in voorbeeld 5 ging het om twee cruciale parameters. Ten eerste de mate waarin nominaal rendement gerelateerd is aan de trend in inflatie. Als bewijs daarvoor gebruikte ik een artikel van Boudoukh en Richardson (1993), gebaseerd op tijdreekseconometrie. Hoewel de auteurs de beste beschikbare technieken gebruiken, mag het op basis van het voorafgaande geen verbazing wekken dat de uitkomsten niet geheel overtuigend zijn. De enige manier om dit probleem aan te pakken is door gebruik te maken van meer data. We kunnen bijvoorbeeld kijken naar de relatie tussen rendement en inflatie over verschillende landen. Als we bereid zijn te veronderstellen dat de relatie in alle landen dezelfde is, en als verder de inflatie niet in ieder land gelijk is, is dit een krachtige methode. We zouden dan willen zien dat gemiddeld genomen het nominale rendement hoger is in landen met een hoge inflatie.

Dat is op zich geen nieuw idee, en werd veel gebruikt voor de opkomst van de tijdreekseconometrie. Een voorbeeld uit de literatuur is Lothian (1985). Pas recent zijn dit soort technieken weer sterk in de belangstelling komen te staan bij de discussie over een vrijwel identiek probleem, namelijk de relatie tussen wisselkoersen en inflatieverschillen tussen landen. ${ }^{14} \mathrm{Ik}$ heb op dit moment heb geen gelegenheid dieper op dit probleem in te gaan. Het is wel een onderzoeksterrein waaraan ik actief deel neem en wil blijven deelnemen. ${ }^{15}$ Helaas voor het onderzoek gaat de invoering van de Euro er waarschijnlijk voor zorgen dat binnen Europa in de toekomst minder variatie in inflatie tussen landen zal bestaan. 
De informatie in marktprijzen

Voor de tweede cruciale parameter, persistentie van inflatie, zullen we gebruik moeten maken van de structuur van theoretische financiële modellen. Ook hier is het idee eenvoudig, en al eerder door anderen gebruikt, maar nog nauwelijks uitgewerkt. Via de contante waarde formule kunnen we berekenen hoe groot het effect van een inflatieschok zal zijn bij een gegeven persistentie. Hoe groter de persistentie, des te heviger zal de koers reageren op een schok (zie ook tabel 1). Als gemiddeld genomen de aandelenkoers 12 procent daalt bij een onverwachte inflatieschok van één procent, dan volgt volgens tabel 1 een halfwaardetijd van 8 jaar, en daarmee hebben we een schatting van de persistentie.

Het grote voordeel van deze methode is dat er geen lange tijdreeksen nodig zijn, omdat aandelenkoersen op elk moment de lange termijn verwachtingen van beleggers weerspiegelen. Als de markt geen systematische fouten maakt, zal deze schattingsmethode veel preciezer zijn dan elke schatting met behulp van pure tijdreeksanalyse. We mogen er immers van uitgaan dat handelaren het probleem zo goed mogelijk proberen op te lossen. Alle handelaren bij elkaar zullen daar zeker meer informatie en kennis bij gebruiken dan alleen het verleden van een klein aantal tijdreeksen.

\section{Voorbeeld 11: Rentedynamiek}

In zijn algemeenheid wil ik hier niet verder op ingaan. Ik wil mij beperken tot resultaten uit mijn eigen onderzoek. Ik heb het meest uitvoerig met dit idee geëxperimenteerd in toepassingen op de termijnstructuur van de rente. ${ }^{16}$ Voor de termijnstructuur van de rente impliceert de contante waarde formule dat de lange termijn rente sterker reageert op de schokken in de korte rente naarmate die schok persistenter is. Voor het hypotheken probleem is het doel om de persistentie van schokken in de korte termijn rente te schatten. Daarvoor gebruiken we de relatie tussen een lange en een korte termijn rente. 
Bij lage rentestanden vonden we dat de lange rente vrijwel één op één reageert op schokken in de korte rente. Dit geeft aan dat de markt denkt dat een schok van één procent in de korte rente tevens een permanente verhoging van de korte rente met één procent tot gevolg heeft. Op de markt leidt dat er toe dat de lange rente eveneens met één procent stijgt. Wanneer de rente hoog is vinden we dat de lange rente nauwelijks reageert op schokken in de korte rente, en dat de lange rente ook vrijwel niet meer toeneemt als de korte rente verder stijgt. Kennelijk verwacht men dat de rente slechts tijdelijk zeer hoog zal zijn, en spoedig zal dalen naar meer normale waarden. Hierdoor waren we niet alleen in staat de gemiddelde persistentie te meten, maar konden we zelfs aangeven dat de persistentie niet altijd gelijk is.

Toch zijn er nog wel wat problemen met deze methode. Niet alle veranderingen in de lange rente kunnen exact verklaard worden met schokken in de korte rente. Naast de korte rente zijn er meer factoren die invloed hebben op de lange rente. Wanneer die factoren gecorreleerd zijn met de korte rente, zal dit een vertekening geven in de schatter voor de persistentie. Verder houdt de theorie geen rekening met ruis. Er is dus nog veel reden voor verder onderzoek. ${ }^{17}$

\section{Ruis}

Met name ruis zal een belangrijke component moeten zijn. De contante waarde formule is misschien te strikt. Net als ieder model is het een abstractie, en dus per definitie niet geheel waar. Datzelfde concludeerden bijvoorbeeld Campbell en Shiller $(1987,1988)$ al in twee invloedrijke artikelen, waarin zij de econometrische methoden ontwikkelen voor het toetsen van de contante waarde formule in het geval de disconteringsvoet constant is. Om die reden is de econometrische gewoonte om aan ieder model een storingsterm toe te voegen die rekening houdt met alles dat niet gemodelleerd is, niet zo gek als vaak door financieel economen wordt beweerd. De theoretische modellen zijn immers zeer gestileerd, al was het alleen maar om ze op te kunnen lossen en er mee te kunnen werken. 
Een groot pleitbezorger van het opnemen van ruis in financiële modellen is Fischer Black. Volgens Black (1986) is een deel van de volatiliteit van rendementen ruis. In zijn rede als president van de American Finance Association geeft hij theoretische redenen waarom financiële data altijd ruis zullen bevatten. Juist omdat er ruis in de koersen zit, ontstaat handel. ${ }^{18}$ Ruis kan zelfs een substantieel bestanddeel van de prijs zijn:

"We kunnen een efficiënte markt definiëren als een markt waarbij de prijs binnen een factor twee van de waarde is, dat wil zeggen de prijs is meer dan de helft van de waarde en minder dan twee keer de waarde".

De nadruk op ruis betekent een groot verschil tussen een econometrische aanpak, en de wiskundige methodologie binnen financiering. Wiskundig economen proberen ruis geheel uit te bannen. Zij construeren een exacte oplossing voor het tijdreeksproces dat op een bepaald moment exact bij de data van die dag past. Voor de termijnstructuur van de rente is het bijvoorbeeld altijd mogelijk een zodanig proces voor de onderliggende factoren te construeren, dat toepassen van de contante waarde formule precies de waargenomen marktprijzen van vandaag oplevert. Heath, Jarrow en Morton (1992) is hiervan het bekendste voorbeeld. Die aanpak heeft voor- en nadelen, afhankelijk van de doel van het model. De vergelijking tussen en integratie van een econometrische en wiskundige benadering van beleggings- en waarderingsproblemen is een mooi onderwerp voor een vervolgcollege. Ik zal $U$ er vanmiddag verder niet mee lastig vallen.

\section{Slotopmerkingen}

Financiële econometrie heeft zich ontwikkeld tot een vakgebied met meer en meer specifieke vragen en methoden die afwijken van hetgeen vereist is bij toepassing van econometrie op macro-economische problemen. Zowel de theoretische modellen als ook de typische financiële data vragen daarom. Dat geldt niet alleen voor het meten 
van persistentie, maar bijvoorbeeld ook voor het meten van risico en prijsvorming op financiële markten. Dit zijn ook stuk voor stuk onderwerpen, waarbij voor de beleggingspraktijk relevante aanbevelingen afhankelijk zijn van empirische inzichten, verkregen met behulp van financiële econometrie. Financiering en econometrie zijn beide van even grote betekenis in de beleggingsleer. Zowel wiskundige vaardigheden als ook de typisch economische manier van redeneren zijn vereist.

Ook in het onderwijs zou dit tot uiting moeten komen. Financiering is een afstudeerrichting binnen Bedrijfseconomie, en trekt vanwege de aard van het vakgebied vaak de meer kwantitatief georiënteerde studenten. Helaas zitten er in de onderbouw van de studie te weinig kwantitatieve vakken, en zijn deze studenten daardoor enigszins in het nadeel ten opzichte van econometristen. Studenten Financiering zouden baat hebben bij een verbreding van de studie in de richting van meer kwantitatieve vaardigheden, ook al gaat dat ten koste van algemene economie of andere bedrijfseconomische disciplines.

Op de arbeidsmarkt voor banen in zowel de financiële praktijk en het onderzoek concurreren econometristen met bedrijfseconomen met de specialisatie Financiering. Een klacht over afgestudeerde econometristen is vaak dat ze te weinig geschoold zijn in economisch denken en redeneren. Het blijft vreemd om een studierichting aan te bieden met een breed scala aan geavanceerde wiskundige technieken bedoeld voor toepassing in allerlei disciplines van Economie en Bedrijfskunde, terwijl de kern van die disciplines zelf maar beperkt aan bod komt. Merkwaardig is ook de opdeling van de studierichting Econometrie in Besliskunde en Econometrische Methoden, dat wil zeggen een opdeling naar wiskundige techniek. Zeker binnen financiering zijn beide typen technieken voor studenten even nuttig. Ook hier zou verdere integratie goed zijn. Dat is gelukkig een trend die op deze faculteit en ook op sommige andere faculteiten in Nederland is ingezet. Op die manier kunnen we een opleiding kunnen aanbieden, die aansluit bij wat een hoogwaardige uitoefening van het vak later eist. 


\section{Dankwoord}

Ter afsluiting van deze inaugurele rede wil ik allereerst alle bestuursorganen in faculteit en universiteit bedanken voor het in mij gestelde vertrouwen. In het bijzonder gaat daarbij mijn dank uit aan collega's Christian Wolff en Kees Koedijk die het initiatief voor het instellen van de leerstoel Financiering en Econometrie hebben genomen.

Dames en heren studenten, Jullie zijn veel meer dan alleen de inspiratie voor deze rede. Ik dank allen die ooit het vak Empirische Analyse van Financiële Markten hebben gevolgd voor hun geweldige inzet, en hoop nog lang te profiteren van de vruchtbare discussies tijdens tutorgroepen.

Geleerde AIO's, en oud-AIO's,

Onze dagelijkse discussies over onderzoek en meer maken dat ik zo'n mooie baan heb. Blijf me lastig vallen over alles; discussies scherpen de geest.

Hooggeleerde Kloek, Beste Teun,

$\mathrm{Jij}$ hebt mijn vroege schreden op het wetenschappelijke pad altijd intensief begeleid, beginnend met werkstukken tijdens het onvolprezen werkcollege econometrie in Rotterdam. Ik dank je voor de manier waarop jij me vele jaren onderwezen hebt in het vak, zorgvuldig en met permanente kritiek.

Beste Pa en Ma,

Aan jullie ben ik meer dank dan aan wie dan ook verschuldigd.

Lieve Nicole,

Jouw bijdragen aan deze rede zijn fundamenteler dan je correcties van mijn Nederlandse tekst.

Ik dank allen die hier aanwezig zijn voor $U$ gewaardeerde aandacht. Ik heb gezegd. 


\section{Literatur}

Bams, W.F.M., en P.C. Schotman (1997) A Panel Data Analysis of Affine Term Structure Models, LIFE working paper 97-43.

Bernstein, P.L., (1992) Capital Ideas: The Improbable Origins of Modern Wall Street, Free Press.

Bernstein, P.L., (1996) Against the Gods, Wiley.

Black, F., (1986) Noise, Journal of Finance, 41, 529-543.

Bollerslev, T., R. Chou en K. Kroner (1992) ARCH Modeling in Finance: A Review of the Theory and Empirical Evidence, Joumal of Econometrics, 52, 5-59.

Bomhoff, E.J., (1994) Financial Forecasting for Business and Economics, Dryden Press.

Boudoukh, J., en M. Richardson (1993) Stock Returns and Inflation: A Long Horizon Perspective, American Economic Review, 83, 1346-1355.

Brealey, R.A., en S.C. Myers (1996) Principles of Corporate Finance, $6^{\text {th }}$ ed., McGraw-Hill.

Bussel, P.J.M. van, (1998) Valuation and Interest Rate Risk of Mortgages in the Netherlands, proefschrift, Universiteit Maastricht.

Campbell, J.Y, A.W. Lo en A.C. MacKinlay (1997) The Econometrics of Financial Markets, Princeton University Press.

Campbell, J.Y., en R.J. Shiller (1987) Cointegration and Tests of Present Value Models, Journal of Political Economy, 95, 1062-1087.

Campbell, J.Y., en R.J. Shiller (1988) Stock Prices, Earnings, and Expected Dividends, Journal of Finance, 43, 661-676.

Cochrane, J.H., (1991) A Critique of the Application of Unit Root Tests, Journal of Economic Dynamics and Control, 15, 275-284.

Cochrane, J.H., (1998) Asset Pricing, draft, University of Chicago.

Deaton, A., (1992) Understanding Consumption, Basil Blackwell.

Fama, E.F., (1991) Efficient Capital Markets II, Journal of Finance, 46, 1575-1618.

Fama, E.F., en G.W. Schwert (1977) Asset Returns and Inflation, Journal of Financial Economics, 5, 115-146.

Frankel, J., en A. Rose (1996) A Panel Project on Purchasing Power Parity: Mean Reversion Within and Between Countries, Journal of International Economics, 40, 209-224.

Friedman, M., (1957) A Theory of the Consumption Function, Princeton University Press.

Goslings, J.H.W., (1990) In wat voor wereld leven we?, oratie, Universiteit Maastricht.

Hamilton, J.D., (1989) A New Approach to the Economic Analysis of Nonstationary Time Series and the Business Cycle, Econometrica, 57, 357-384. 
Haugen, R.A., (1995) The New Finance: The Case against Efficient Markets, Prentice Hall.

Heath, D., R.A. Jarrow, en A. Morton (1992) Bond Pricing and the Term Structure of Interest Rates: A New Methodology for Contingent Claims Pricing, Econometrica, 60, 77-105.

Hendry, D.F., (1995) Dynamic Econometrics, Oxford University Press. Hull, J.C., en A. White (1987) The Pricing of Options on Assets with Stochastic Volatilities, Journal of Finance, 42, 281-300.

Jacquier, E., and R.A. Jarrow (1998) Dynamic Evaluation of Contingent Claims Models: An Analysis of Model Error, verschijnt in Journal of Econometrics.

Juselius, K., (1995) Do Purchasing Power Parity and Uncovered Interest Rate Parity Hold in the Long Run?, Journal of Econometrics, 69, 211-240. Kemna, A.G.Z., (1996) De onstuitbare opmars van kwantitatief beleggen,0ratie, Universiteit Maastricht.

Koedijk, C.G., (1993) Nooit Meer Slapen, oratie, Universiteit Maastricht. Koedijk, C.G., F.G.J. Nissen, P.C. Schotman en C.C.P. Wolff (1997) The Dynamics of Short Term Interest Rate Volatility Reconsidered, European Finance Review, 1, 105-130.

Koedijk, C.G., P.C. Schotman and M. van Dijk (1998) The Re-emergence op PPP in the nineties, verschijnt in Journal of International Money and Finance.

Lothian, J.R., (1985) Equilibrium Relationships between Money and Other Economic Variables, American Economic Review, 75, 828-835.

Mahieu, R.J., en P.C. Schotman (1998) An Empirical Application of Stochastic Volatility Models, verschijnt in Journal of Applied Econometrics.

McCloskey, D.N., (1997) The Vices of Economists -- The virtues of the Bourgeoisie, Amsterdam University Press.

Munnik, J.F.J. de, en P.C. Schotman (1994) Cross Sectional versus Time Series Estimation of Term Structure Model: Empirical Results for the Dutch Bond Market, Journal of Banking and Finance, 18, 997-1025.

Nelson, C.R., en C.I. Plosser (1982) Trends and Random Walks in Macroeconomic Time Series, Journal of Monetary Economics, 10, 139-162.

Nijman, T.E., (1993) De Data van de Econometrie, oratie, Katholieke Universiteit Brabant.

O'Connell, P., (1998) The Overvaluation of Purchasing Power Parity, Journal of International Economics

Perron, P., (1989) The Great Crash, the Oil Price Shock, and the Unit Root Hypothesis, Econometrica, 57, 1361-1401.

Pfann, G.A., P.C. Schotman en R. Tschernig (1996) Nonlinear Interest Rate Dynamics and Implications for the Term Structure, Journal of Econometrics, 74, 149-176. 
Samuelson, P.A., (1965) Proof that Properly Anticipated Prices Fluctuate Randomly, Industrial Management Review, 6, 41-50.

Schotman, P.C., (1996) A Bayesian Approach to the Empirical Valuation of Bond Options, Journal of Econometrics, 75, 183-215.

Schotman, P.C., en M. Schweitzer (1998) Horizon Sensitivity of the Inflation Hedge of Stocks, ongepubliceerd manuscript, Universiteit Maastricht. Schotman, P.C., en P.J.M. van Bussel (1998), Multi-Factor Interest Rate Models and the Valuation of Dutch Mortgages, ongepubliceerd manuscript, Universiteit Maastricht.

Shiller, R.J., (1981) Do Stock Prices Move too much to be Justified by Subsequent Changes in Dividends, American Economic Review, 71, 421436.

Vorst, A.C.F., (1989) Economie, Onzekerheid en Wiskunde, oratie, Erasmus Universiteit Rotterdam.

Wolff, C.C.P., (1989) Pensioenverzekering?, oratie, Universiteit Maastricht.

\section{Noten}

1. McCloskey (1997, p 103). Bij het uitspreken van deze rede heb ik citaten zoveel mogelijk uit het Engels in het Nederlands vertaald.

2. Zie Bernstein (1992) voor een geschiedenis van de ontwikkeling van de moderne beleggingsleer.

3. Er valt econometrisch wel wat af te dingen op deze conclusie. Een beursindex is bijvoorbeeld het gemiddelde van een groot aantal individuele aandelen, die onderling niet perfect gecorreleerd zijn. De standaardfout op het gemiddelde van het gemiddelde rendement is daarom zeker kleiner dan in het voorbeeld.

4. Auteurs van tekstboeken zijn zich bewust van de soms absurde uitkomsten van het model en waarschuwen dat het gevaarlijk is aan te nemen dat een bedrijf eeuwig dezelfde groei zal laten zien. Zie bijvoorbeeld Brealey en Myers (1996).

5. Zie bijvoorbeeld Wolff (1989), Goslings (1990), Nijman (1993), Koedijk (1994) en Kemna (1995).

6. Het model berust op empirische resultaten in de literatuur. De klassieke referentie voor een korte termijn negatieve correlatie tussen rendement en inflatie is Fama en Schwert (1977). Persistentie van inflatie is onderzocht in onder andere Juselius (1995). De lange termijn positieve relatie tussen inflatie en rendement komt uit Boudoukh en Richardson (1993).

7. De volgende berekeningen ontleen $\mathrm{ik}$ aan gezamenlijk onderzoek in Schotman en Schweitzer (1998). 
8. Zie Haugen (1995, hoofdstukken 4 en 7). De kerstboom verwijst naar figuur 4.5 op p. 52.

9. Strikt genomen is de Black-Scholes formule niet toepasbaar. We kunnen niet het effect van een verandering in een van de parameters bespreken, als we eerder verondersteld hebben dat alle beleggers het erover eens dat die niet zal veranderen. Als dat blijkbaar toch kan, dan houden beleggers hier ook rekening mee bij het waarderen van de optie. Dit is niets anders dan een toepassing van de Lucas kritiek op financiële modellen.

10. GARCH effecten treden op in alle financiële tijdreeksen. Zie Bollerslev, Chou en Kroner (1995) voor een overzicht en inleiding van de GARCH literatuur.

11. Afgezien van het schattingsprobleem wordt de optiewaardering in dit geval ook nog bemoeilijkt doordat we een aanname moeten doen omtrent de prijs van volatiliteitsrisico. Zie Hull en White (1987).

12. Een gedetailleerde analyse voert te ver in het kader van deze oratie. Het proefschrift Van Bussel (1998) gaat hier dieper op in. Zie met name de hoofdstukken 5 en 7. Zie ook Koedijk, Nissen, Schotman en Wolff (1997).

13. Zie bijvoorbeeld Perron (1989) en de literatuur over regime veranderingen beginnend bij Hamilton (1989).

14. Zie Frankel en Rose (1996) en O'Connell (1998). Kern van de discussie is dat ontwikkelingen in verschillende landen niet ongecorreleerd zijn.

15. Zie bijvoorbeeld Koedijk, Schotman en Van Dijk (1998).

16. De resultaten die ik beschrijf hebben betrekking op Pfann, Schotman en Tschernig (1996). Hetzelfde onderwerp wordt behandeld in De Munnik en Schotman (1994), Schotman (1996), Schotman en Van Bussel (1998) en Bams en Schotman (1997).

17. Zie bijvoorbeeld Bams en Schotman (1997), waarin panel-data methoden worden ontwikkeld om termijnstructuur modellen te schatten en toetsen.

18. Black (1986): "If there is no noise trading, there will be very little trading in individual assets." Recent hebben Jacquier en Jarrow (1998) ruis expliciet onderdeel gemaakt van een econometrische analyse van optieprijsmodellen. 